\title{
Conceptualisations of Leadership and Relevance to Health and Human Service Workforce Development: A Scoping Review
}

\section{Kate Fennell (iD}

Health and Human Services Leadership, University of Tasmania, Tasmanian School of Medicine, College of Health and Medicine, Medical Science Precinct, Hobart, Tasmania, 7000, Australia
Correspondence: Kate Fennell Health and Human Services Leadership, University of Tasmania, Tasmanian School of Medicine, College of Health and Medicine, Medical Science Precinct, 17 Liverpool Street, Hobart, Tasmania, 7000, Australia

Email kate.fennell@utas.edu.au
Purpose: This scoping review was undertaken to determine leadership definitions and approaches relevant to health and human service (H\&HS) workforce development. This review provides a preliminary analysis of the potential size and scope of available research literature to inform ongoing research with the ultimate aim to inform a future systematic review in relation to leadership development interventions.

Methods: Following the methodology proposed by Arksey and O'Malley and using PRISMAScR, a systematic search was conducted using seven databases (PubMed, Health Business Elite, Medline, CINAHL, Ovid, Scopus, and Web of Science). Articles were screened and assessed for eligibility. From eligible studies, data were extracted to summarize, collate, and make a narrative account of the findings.

Results: Employing pre-selected criteria, a total of 424 records were identified and 171 fulltext articles were assessed. The majority of the papers were studies undertaken by researchers based in North America. Leadership in the H\&HS sector was addressed in $35 \%$ of the articles. The narrow disciplinary or workforce fields of the nursing and medical professions in hospitals and acute care settings dominated the literature.

Conclusion: The findings suggest that while leadership has been studied extensively in the health system, there is a paucity of leadership development research specific to the broader H\&HS sector. This review emphasises the need for further research, including a more critical examination of leadership development interventions and their application to the H\&HS sector.

Keywords: leadership, development, health and human services, workforce development, scoping review

\section{Introduction}

There is widespread recognition of the importance of leadership and leadership development in the health and human service (H\&HS) sectors. ${ }^{1-3}$ This is particularly relevant for workforce development in these sectors with leadership development being a major strategic focus related to capacity-building initiatives and strategies. $^{4-8}$ Leadership development is a ubiquitous yet ambiguous focus of H\&HS workforce development. ${ }^{9-11}$

"Leadership is like the abominable snowman whose footprints are everywhere but who is nowhere to be seen". ${ }^{2}$ Leadership has been defined by many and yet there does not appear to be a universally accepted definition, and the term has different meanings to different people and different contexts. ${ }^{13-20}$ Most leadership 
theories and definitions have stemmed from a business context and are then adapted to the H\&HS sector. ${ }^{21-23}$ This lack of a specific definition of leadership in the H\&HS sector was identified by Berghout et $\mathrm{al}^{24}$ in a systematic review of medical leadership in which they acknowledged that the lack of conceptual understanding and commonly used terminology hampers empirical developments in leadership research for this sector. Thus, there is a need for more research of leadership development specific to the H\&HS sector.

Developing a working definition of leadership as it relates to the H\&HS sector is the key starting point to add precision to this research by removing the multiplicity of meaning that can be attributed to this concept. ${ }^{25}$ Suddaby $^{26}$ argues that a good definition is needed to capture the essential properties and characteristics of the concept under consideration. Definitions of the human services continue to be difficult and contested because this workforce is responsible for a broad variety of functions and tasks, with roles performed by a diverse array of people from different disciplines, with various qualifications, and with a variety of knowledge bases and approaches in diverse environments. ${ }^{27}$ Human Services is not a single service delivery system, but a complex network of organisations whose primary goal is to help people in need. It encompasses, but is not limited to, disability services; aged services; child, youth, and family services; corrections; social housing; crisis intervention; and education. ${ }^{28}$ In contrast, the health system has been clearly defined as all organizations, people and actions whose primary intent is to promote, restore or maintain health. ${ }^{29}$

This scoping review was conducted with three objectives: (a) to identify a definition of leadership applicable to the H\&HS sector (b) to identify and describe the theories and approaches to leadership and the relevance to H\&HS sector workforce development with a view to informing a future predetermined systematic review in relation to leadership development interventions and (c) to provide a preliminary analysis of the potential size and scope of available research literature to inform ongoing research. $^{30-33}$

\section{Methodology}

The scoping review methodology developed by Arksey and O'Malley ${ }^{34}$ refined by Levac et $\mathrm{al}^{35}$ with enhanced guidance from the Joanna Briggs Institute Manual ${ }^{33}$ informed this review. Scoping reviews are exploratory and descriptive with one of the key values being the ability to incorporate various types of the literature that are not limited to research studies. ${ }^{36-38}$

\section{Search Strategy and Criteria}

Search terms were derived from the research question and included "leadership", "leadership theory", "leadership definition", "health sector", "human services", and "health and human services". These were used both alone and in combination. In an iterative process, various combinations of the key words were tested in keeping with the scoping review methodology. ${ }^{34}$ The final search string was as follows: "leadership", "leadership AND definition", "leadership AND theory" "leadership AND definition AND theory", limit to English, AND "health and human services". The identification of key words and the selection of search strings using Boolean logic is important to determine what material you retrieve. ${ }^{39,40}$ The search included journal articles, dissertations, book chapters, and conference proceedings as identified in each database.

Seven databases were searched: PubMED, Health Business Elite, Medline, CINAHL, Ovid, Scopus and Web of Science. These databases were identified for their relevance to H\&HS sector leadership. The initial search was conducted in September 2020 and repeated in April 2021.

The inclusion and exclusion criteria for each phase of the review are detailed in Table 1. Articles were excluded if they did not meet all inclusion criteria. If the information provided in either the title and/or the abstract was insufficient for a justified decision, the articles were included in the full-text screening phase. Screening of reference lists and hand searching of known journals for newly published articles was also undertaken.

In accordance with the standard approach to conducting scoping reviews, a quality appraisal was not performed. $^{37,38}$

\section{Results}

The initial search yielded 424 articles. After removal of duplicates and application of the exclusion criteria, there were 73 articles remaining to analyze. The research has also been informed by seminal works and by examining the bibliographies of resources identified through the screening process, which provided further 47 articles or books. A total of 171 articles met the eligibility criteria and were reviewed. The PRISMA flowchart (see Figure 1) illustrates the screening process that resulted in articles to be included in the scoping review. ${ }^{36,41,42}$ 
Table I Inclusion and Exclusion Criteria

\begin{tabular}{|c|c|c|}
\hline Phase of Review & Inclusion Criteria & Exclusion Criteria \\
\hline \multirow[t]{2}{*}{$\begin{array}{l}\text { Title and Abstract } \\
\text { Screening }\end{array}$} & $\begin{array}{l}\text { Peer reviewed articles with leadership definition and theory } \\
\text { in the title and/or abstract }\end{array}$ & $\begin{array}{l}\text { Not peer reviewed or did not contain the word leadership } \\
\text { in the title and/or abstract } \\
\text { Opinion papers } \\
\text { Articles based on theories not concerned with leadership }\end{array}$ \\
\hline & English language & Not published in English \\
\hline Full Text Screening & $\begin{array}{l}\text { Studies focused on; } \\
\text { - Leadership } \\
\text { - Leadership definition } \\
\text { - Leadership theory } \\
\text { - Leadership approaches } \\
\text { - Health and human services }\end{array}$ & $\begin{array}{l}\text { Studies focused on; } \\
\text { - Clinical Care } \\
\text { - Children and adolescents } \\
\text { - Training } \\
\text { - Organizational factors and processes (eg, Job } \\
\text { satisfaction, integrity) } \\
\text { - Health policy } \\
\text { - Project management } \\
\text { - Trauma } \\
\text { - Gender/Cultural studies } \\
\text { - Sectors not concerned with health and/or human services }\end{array}$ \\
\hline
\end{tabular}

\section{Characteristics of the Included Papers}

Initial examination of the papers resulted in the following observations. The largest share of the papers reviewed was review articles (38\%) followed by qualitative studies (22\%). Literature reviews (7\%), books (7\%) and systematic review (3\%) papers were the next most common. Only 4 quantitative studies were located. The geographical distribution of the publications by author/s was predominantly USA (56\%) followed by the UK (10\%), Canada (5\%) and Australia (3\%). Of the 171 papers reviewed only 61 (35\%) specifically addressed leadership in the H\&HS sector.

\section{Evolution of the Definition of Leadership}

This review of the literature demonstrates the diversity and variety of opinions that exist when one attempts to define leadership. This review demonstrates that definitions of leadership have evolved over time (refer Table 2). Leadership has moved from power "over" people to working "with" people to achieve the desired outcomes. In most health settings, old practices such as command and control have become obsolete and are unsustainable. Key components that have been identified as pivotal are that leadership is a process, it involves influence, occurs between people, and involves attainment of goals (which may be individual, group or organizational). ${ }^{43-45}$

\section{Leadership Theories and Approaches: Historical Overview}

Historically, the concept of leadership has been extensively studied and analyzed by researchers, resulting in an evolving succession of theories and approaches. This historical overview, based on the findings of this scoping review, demonstrates that the early theories focused on the traits or innate qualities of the leaders with later theories expanding to include the context in which leadership takes place. Whilst it is difficult to divide the theories and approaches into specific timeframes, it is possible to demonstrate the evolutionary development, as identified in this scoping review, and potential applicability to the H\&HS sector (refer Table 3,).

The earlier theories and approaches considered that there was one factor that determined leadership be they innate traits, ${ }^{44,47,54-60}$ a set of skills, ${ }^{44,61-63}$ certain behaviours, ${ }^{44,47,64}$ or a certain style. ${ }^{13,44,47,65-68}$ Particular traits and characteristics that have been shown to promote leadership are openness, extroversion, self-confidence, energy, inclusiveness, and motivation to manage. ${ }^{47,55-57}$ The strength of the skills approach was that it categorized leadership as an identifiable set of skills, which can be learned, developed and improved, instead of being a concept reserved for the select few born with the ability. ${ }^{44}$ Researchers then identified two general types of leadership behaviours: task behaviours and relationship 


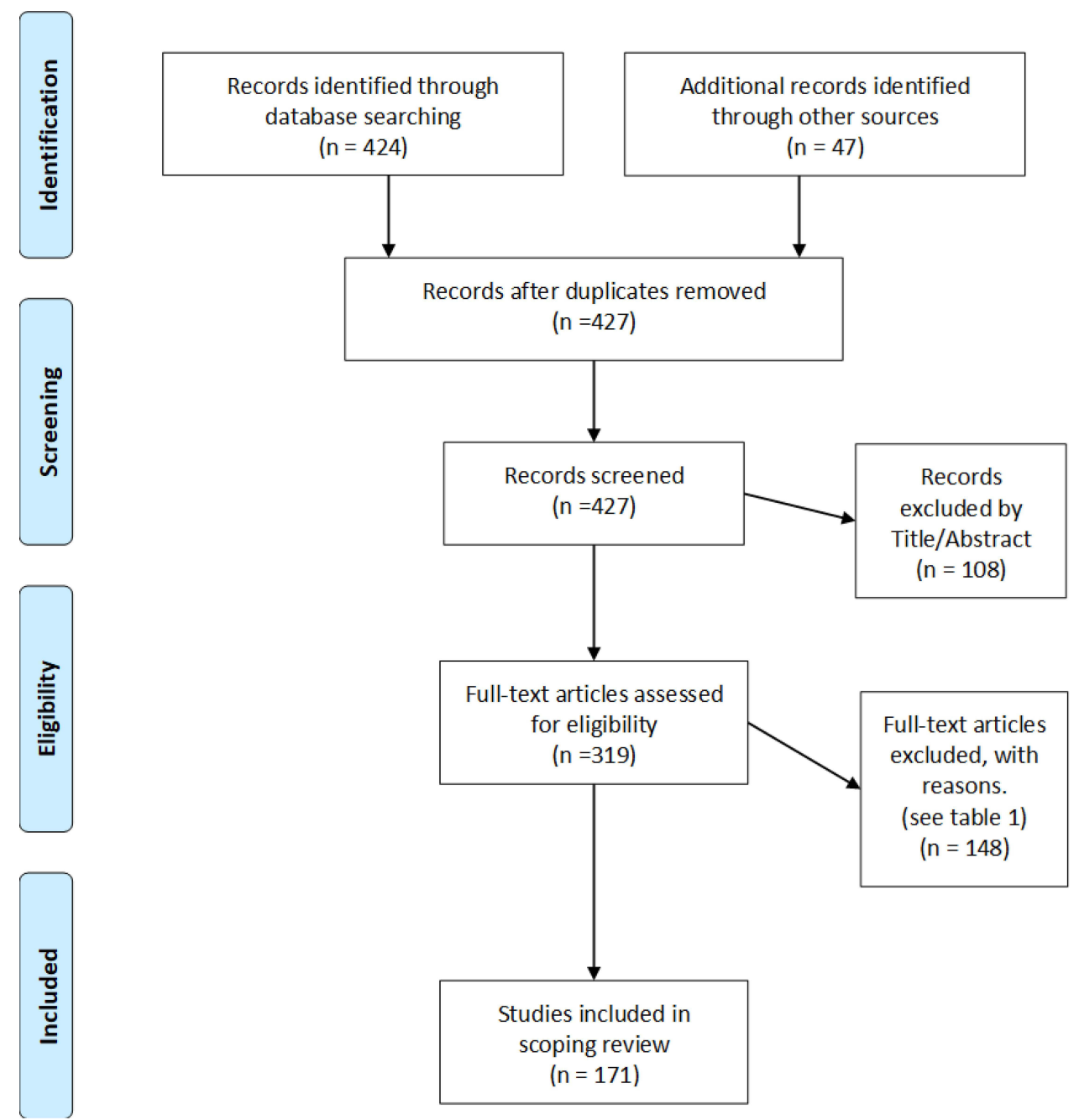

Figure I PRISMA flow diagram for the scoping review process.

Note: Adapted from Moher D, Liberati A, Tetzlaff J, Altman DG; The PRISMA Group. Preferred reporting items for systematic reviews and meta-analyses: the prisma statement. PLoS Med. 2009;6(7):el000097. doi:I0.137I/journal.pmed.1000097. ${ }^{42}$

behaviours, and this approach aimed to explain how leaders made decisions and identified their primary areas of concern. $^{44}$ The styles approach emphasized patterns of leadership that are categorized as democratic, autocratic, and laissez-faire. $^{44,47}$

Understanding that these leader-centric theories and approaches had many shortcomings, researchers started to combine factors resulting in the emergence of the Situational Approach. This approach asserted that effective leaders adapt their leadership style to the context and to meet the needs and abilities of their followers, and includes life-cycle theory, contingency theory, and pathgoal theory. ${ }^{13,44,47,50,53,69-74}$ Whilst these theories have a strong history of use in the marketplace, there has been limited research to justify the assumptions and propositions set forth with critics highlighting conceptual weaknesses, ambiguous constructs, oversimplification, and lack of intervening explanatory processes, as well as the fact that the approach does not address the issue of individual versus group leadership. ${ }^{13,44,47,60}$

Leader-Member Exchange (LMX) theory is based on the nature and quality of the relationship between the leader and followers. The theory asserts that the more positive the interactions, the better organizational outcomes. ${ }^{44}$ In LMX, followers are divided into "in group" or "out group" based on their relationships with leadership. "In" group members are those with whom the leader has a high-quality relationship with trust, communication, respect, and commitment as identifying features. ${ }^{44,75,76}$ "Out" group members are those with whom the leader has a low-quality relationship 
Table 2 Evolution of the Definitions of Leadership

\begin{tabular}{|c|c|c|}
\hline Author & Date & Definition of Leadership \\
\hline Burns ${ }^{46}$ & 1978 & $\begin{array}{l}\text { "Leadership over human beings is exercised when persons with certain motives and purposes mobilize, in } \\
\text { competition or conflict with others, institutional, political, psychological, and other resources so as to arouse, } \\
\text { engage, and satisfy the motives of followers" }\end{array}$ \\
\hline Yukl $^{47}$ & 1989 & $\begin{array}{l}\text { "Leadership is defined broadly in this article to include influencing task objectives and strategies, influencing } \\
\text { commitment and compliance in task behaviour to achieve these objectives, influencing group maintenance and } \\
\text { identification, and influencing the culture of an organization". }\end{array}$ \\
\hline Bass $^{48}$ & 1990 & $\begin{array}{l}\text { "An interaction between two or more members of a group that often involves a structuring or restructuring of the } \\
\text { situation and the perceptions and expectations of the members". }\end{array}$ \\
\hline Rost $^{49}$ & 1991 & $\begin{array}{l}\text { "Leadership is an influence relationship among leaders and followers who intend real changes and reflect their } \\
\text { mutual purposes" }\end{array}$ \\
\hline Vroom and Jago 50 & 2007 & A process of motivating people to work together collaboratively to accomplish great things \\
\hline Yukl $^{43}$ & 2012 & $\begin{array}{l}\text { A process whereby intentional influence is exerted by one person over other people to guide, structure and } \\
\text { facilitate activities and relationships in a group or organization }\end{array}$ \\
\hline Branchini $^{51}$ & 2012 & $\begin{array}{l}\text { A complex emerging process in which the content, context and characteristics of agency are orchestrated in } \\
\text { dynamic interplay with the environments in which they function, to result in achievement of a desired outcome }\end{array}$ \\
\hline $\begin{array}{l}\text { Smith and } \\
\text { Cockburn }^{52}\end{array}$ & 2014 & $\begin{array}{l}\text { "A process of continuous optimization and adaption, where the next leadership action is based on what is happening } \\
\text { now. In other words, leadership is emergent, and is co-developed with the context in which the leadership is taking } \\
\text { place" }\end{array}$ \\
\hline Northouse $^{44}$ & 2018 & A process whereby an individual influences a group of individuals to achieve a common goal \\
\hline Belrhiti et al ${ }^{53}$ & 2018 & $\begin{array}{l}\text { A behaviour or set of behaviours that emerges from the interaction among individuals and groups in organizations } \\
\text { occurring throughout the whole organisation, and not a role or function formally assigned to an individual }\end{array}$ \\
\hline $\begin{array}{l}\text { Van Dick and } \\
\text { Monzani }^{45}\end{array}$ & 2020 & An interactive process of reciprocal influence where social actors interact with each other and their context \\
\hline
\end{tabular}

characterised by limited trust, formal communication based on formalized organizational roles and transactional interactions. $^{44,75,76}$ With more than 35 years of research, including evidence from multiple cultures, the theory has been demonstrated to provide potential in the area of health information management. ${ }^{76}$ Criticisms of the theory cite the appearance of being unfair and discriminatory; ${ }^{44,47}$ how it does not identify a specific guide to the process of relationship building, which is central to the theory; ${ }^{47,76}$ and there is limited evidence of actual practical applications of the LMX model. ${ }^{13}$ An extensive body of research undertaken by Gottfredson et al uncovered numerous issues leading to the conclusion that LMX is not a valid construct and therefore incapable of serving the needs of the theories it has traditionally served and is unlikely to advance leadership theory and practice in significant or meaningful ways. ${ }^{77}$

Transactional leadership theories are based on the premise that the leader attempts to motivate followers behaviour through the promise of rewards. ${ }^{14,44,78}$ While
Burns $^{46}$ saw transactional and transformational as two distinct styles of leadership, Bass ${ }^{14}$ identified that both these elements are required and that leaders will use them in varying amounts. Transactional leadership involves both the leader and follower getting something for their efforts. Transactional leadership is task-oriented, and reward driven with an underlying assumption that team members have no self-motivation. ${ }^{44,79}$ It has been argued that transactional leadership is more about management and is really only appropriate in selected situations. $^{20,80,81}$

Transformational theories have been widely studied, researched, and advocated for many years. ${ }^{13,44,53,82,83}$ These theories focus on how leaders can "transform" their followers and elevate, empower and develop teams. ${ }^{46,47}$ There is an emphasis on vision, innovation, motivation, empowerment, inspiration, and communication. ${ }^{12,14,44,80,83-86}$ Kouzes and Posner argue that anyone can become a leader and that leadership is 
not reserved for those with special talent but can be learned and mastered through education and practice. ${ }^{86}$

Transformational leadership is intuitively appealing, places a strong emphasis on the empowerment of others and has been purported to be an effective form of leadership. ${ }^{44,79,82,85}$ Criticisms of transformational leadership include lack of conceptual clarity with an overlap between the key constructs, treating leadership as a personality trait, bias toward executive and heroic notions of leadership, lack of a causal link between transformational leaders and changes in organizations or their teams and that it has

Table 3 Synopsis of Leadership Theories and Approaches

\begin{tabular}{|c|c|c|c|c|}
\hline Theory & Date & Description & Strengths/Weaknesses & Relevance to H\&HS \\
\hline Great Man Theory ${ }^{160}$ & $1840 \mathrm{~s}$ & $\begin{array}{l}\text { Rare individuals were born with } \\
\text { unique characteristics that } \\
\text { predisposed them to take } \\
\text { command and lead others. Based } \\
\text { on the idea that leaders were born } \\
\text { to rule. }\end{array}$ & $\begin{array}{l}\text { The heroic leader as an influential } \\
\text { person that comes to prominence } \\
\text { when needed. } \\
\text { Key weakness is the lack of } \\
\text { scientific evidence for the theory. }\end{array}$ & $\begin{array}{l}\text { Outdated theory providing little } \\
\text { value to } \mathrm{H} \& \mathrm{HS} \text { leadership. }\end{array}$ \\
\hline Trait Approach ${ }^{44,58,161}$ & $1930 \mathrm{~s}$ & $\begin{array}{l}\text { This approach asserted that } \\
\text { leaders demonstrate certain } \\
\text { physical, social, and personal } \\
\text { characteristics that make them } \\
\text { better suited to leadership. Whilst } \\
\text { great man theory contends that } \\
\text { traits are inherited, trait theory } \\
\text { does not specify where they come } \\
\text { from. }\end{array}$ & $\begin{array}{l}\text { Particular traits shown to promote } \\
\text { leadership are openness, } \\
\text { extroversion, self-confidence, } \\
\text { energy, inclusiveness, and } \\
\text { motivation to manage. } \\
\text { Conversely, there is no consensus } \\
\text { on a definitive list of leadership } \\
\text { traits that are consistently } \\
\text { associated with great leaders. }\end{array}$ & $\begin{array}{l}\text { Pure trait theory fails to identify } \\
\text { all variables for H\&HS leadership. }\end{array}$ \\
\hline Skills Approach ${ }^{44,61-63,162}$ & $1940 \mathrm{~s}$ & $\begin{array}{l}\text { This leader-centric approach } \\
\text { focussed on the acquired skills that } \\
\text { the leader requires to perform } \\
\text { rather than on personality traits } \\
\text { with the implication that these } \\
\text { skills can be learned. }\end{array}$ & $\begin{array}{l}\text { Key strength is that this approach } \\
\text { categorised leadership as an } \\
\text { identifiable set of skills which can } \\
\text { be learned, developed, and } \\
\text { improved. } \\
\text { Weakness is the lack of precision } \\
\text { and inability to identify how } \\
\text { variations in the skills will lead to } \\
\text { positive leadership performance. }\end{array}$ & $\begin{array}{l}\text { A pure skills approach also fails } \\
\text { to identify all variables for H\&HS } \\
\text { leadership. }\end{array}$ \\
\hline Styles Approach ${ }^{67,68,81,163,164}$ & 1940s & $\begin{array}{l}\text { This approach asserts that } \\
\text { different styles of leadership may } \\
\text { be more appropriate for different } \\
\text { types of decision-making and } \\
\text { ultimately influence the success of } \\
\text { an organization. Leadership styles } \\
\text { are categorized as democratic, } \\
\text { autocratic, or laissez-faire. }\end{array}$ & $\begin{array}{l}\text { Similar to the Behavioural } \\
\text { Approach this is easy to } \\
\text { understand and has been validated } \\
\text { through research. } \\
\text { Key Weakness with this approach } \\
\text { is that no one style have been } \\
\text { identified as suitable for all } \\
\text { situations or contexts. }\end{array}$ & $\begin{array}{l}\text { A pure styles approach also fails } \\
\text { to identify all variables for H\&HS } \\
\text { leadership. }\end{array}$ \\
\hline $\begin{array}{l}\text { Behavioural } \\
\text { Approach }^{44,64,115,165}\end{array}$ & $1950 \mathrm{~s}$ & $\begin{array}{l}\text { This approach focussed on what } \\
\text { leaders do. The theories assert } \\
\text { that different patterns of behaviour } \\
\text { are observed in successful leaders } \\
\text { with leaders being either task- } \\
\text { oriented or people-orientated. }\end{array}$ & $\begin{array}{l}\text { Strengths are that it is easy to } \\
\text { understand and has been validated } \\
\text { by a broad range of studies. } \\
\text { Weakness is that despite } \\
\text { a substantial research base the } \\
\text { results have been contradictory } \\
\text { and inconclusive and has not } \\
\text { identified universal behaviours } \\
\text { associated with effective } \\
\text { leadership. }\end{array}$ & $\begin{array}{l}\text { A pure behavioural approach } \\
\text { also fails to identify all variables } \\
\text { for H\&HS leadership. }\end{array}$ \\
\hline
\end{tabular}

(Continued) 
Table 3 (Continued).

\begin{tabular}{|c|c|c|c|c|}
\hline Theory & Date & Description & Strengths/Weaknesses & Relevance to H\&HS \\
\hline $\begin{array}{l}\text { Situational/Contingency } \\
\text { Approaches }{ }^{50,69,71-74,166}\end{array}$ & 1960s & $\begin{array}{l}\text { This approach asserted that } \\
\text { effective leaders use a combination } \\
\text { of styles that are contingent upon } \\
\text { the particular situation, the } \\
\text { personalities involved, the task, } \\
\text { and the organizational context. } \\
\text { These approaches demonstrate } \\
\text { the evolution of leadership theory } \\
\text { from the one-dimensional leader- } \\
\text { centric approaches discussed } \\
\text { above. }\end{array}$ & $\begin{array}{l}\text { Key strength of this approach is that it } \\
\text { allows the leader to be more flexible } \\
\text { in their approach as it also considers } \\
\text { the situation or context. } \\
\text { Identified weaknesses are the lack of } \\
\text { a strong body of research, the } \\
\text { ambiguous conceptualisation of the } \\
\text { followers developmental levels and } \\
\text { the fact that the approach does not } \\
\text { address the issue of individual versus } \\
\text { group leadership. }\end{array}$ & $\begin{array}{l}\text { The inclusion of multiple } \\
\text { variables provides potential for } \\
\text { informing H\&HS leadership, but } \\
\text { the indistinct concepts make } \\
\text { these difficult to implement. }\end{array}$ \\
\hline $\begin{array}{l}\text { Leader Member Exchange } \\
(\text { LMX) }\end{array}$ & 1970s & $\begin{array}{l}\text { This theory focuses on the } \\
\text { relationship between leaders and } \\
\text { followers and the psychological } \\
\text { effect of leaders building positive } \\
\text { or negative relationships with } \\
\text { employees. LMX theory explains } \\
\text { that in any organization, there are } \\
\text { in-group members and out-group } \\
\text { members. }\end{array}$ & $\begin{array}{l}\text { A key strength of this theory is that } \\
\text { it validates how people within } \\
\text { organizations relate to each other } \\
\text { and directs our attention to the } \\
\text { importance of communication in the } \\
\text { leader-follower relationship. } \\
\text { Weaknesses are that it does not } \\
\text { identify a specific guide to the } \\
\text { process of relationship building and } \\
\text { there is limited evidence of actual } \\
\text { practical applications. }\end{array}$ & $\begin{array}{l}\text { Demonstrated potential in health } \\
\text { information management }\end{array}$ \\
\hline Transactional Theories ${ }^{14,46,48}$ & 1970s & $\begin{array}{l}\text { In this theory the focus is on the } \\
\text { exchange of value between } \\
\text { employee performance and the } \\
\text { leader's response to it. Based on } \\
\text { systems of reinforcement and } \\
\text { punishment this theory is task } \\
\text { orientated. Also known as } \\
\text { management theories. }\end{array}$ & $\begin{array}{l}\text { Strength is the simplicity of the } \\
\text { theory. Transactional leaders set } \\
\text { goals and standards for employees } \\
\text { and provide rewards in return for } \\
\text { them being met. Biggest weakness is } \\
\text { the assumption that everyone can be } \\
\text { motivated by reward and } \\
\text { punishment. }\end{array}$ & $\begin{array}{l}\text { Limited value in } \mathrm{H} \& \mathrm{HS} \\
\text { leadership with applicability in } \\
\text { selected situations. }\end{array}$ \\
\hline 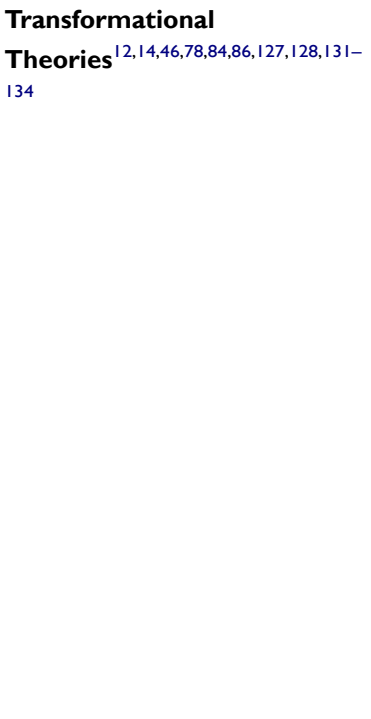 & 1980s & $\begin{array}{l}\text { Transformational leadership } \\
\text { encompasses idealised influence } \\
\text { (charisma), inspirational } \\
\text { motivation, individualized } \\
\text { consideration and intellectual } \\
\text { stimulation, with the leader } \\
\text { maintaining a continuous challenge } \\
\text { to followers by espousing new and } \\
\text { innovative ideas and approaches. } \\
\text { This theory is one of the most } \\
\text { studied, researched and advocated } \\
\text { theories, and were seen as an } \\
\text { improvement over earlier theories. }\end{array}$ & $\begin{array}{l}\text { Theory is intuitively appealing, } \\
\text { places a strong emphasis on the } \\
\text { empowerment of others and has } \\
\text { been purported to be an effective } \\
\text { form of leadership. } \\
\text { Criticisms of transformational } \\
\text { leadership include lack of } \\
\text { conceptual clarity with an overlap } \\
\text { between the key constructs, } \\
\text { treating leadership as a personality } \\
\text { trait, bias toward executive and } \\
\text { heroic notions of leadership, lack } \\
\text { of a causal link between } \\
\text { transformational leaders and } \\
\text { changes in organizations/ teams } \\
\text { and that it has the potential to be } \\
\text { abused as it is concerned with } \\
\text { changing people's values }\end{array}$ & $\begin{array}{l}\text { Potential to inform H\&HS } \\
\text { leadership has been identified in } \\
\text { numerous studies across multiple } \\
\text { settings. }\end{array}$ \\
\hline
\end{tabular}

(Continued) 
Table 3 (Continued).

\begin{tabular}{|c|c|c|c|c|}
\hline Theory & Date & Description & Strengths/Weaknesses & Relevance to H\&HS \\
\hline $\begin{array}{l}\text { Authentic Leadership } \\
\text { Theory }^{88-92,135-139}\end{array}$ & 1980s & $\begin{array}{l}\text { Emphasizes the values system of } \\
\text { the leader and its role in leading } \\
\text { from a base of self-awareness, } \\
\text { integrity, compassion, } \\
\text { interconnectedness, and self- } \\
\text { discipline. Builds on from } \\
\text { Transformational theory and } \\
\text { includes charismatic leadership } \\
\text { theory. }\end{array}$ & $\begin{array}{l}\text { Take the positives from } \\
\text { Transformational theory and add } \\
\text { a values orientation. } \\
\text { Weaknesses identified include that } \\
\text { the theory has not been } \\
\text { substantiated, over-emphasis on } \\
\text { person-centred factors and } \\
\text { perpetuation of the 'heroic leader'. }\end{array}$ & $\begin{array}{l}\text { Demonstrated applicability in } \\
\text { healthcare settings but needs to } \\
\text { be tested in a variety of } \\
\text { populations and settings. }\end{array}$ \\
\hline $\begin{array}{l}\text { Servant Leadership } \\
\text { Theory }^{93-96}\end{array}$ & 1990s & $\begin{array}{l}\text { A multidimensional leadership } \\
\text { theory that starts with a desire to } \\
\text { serve followed by the intent to } \\
\text { lead and develop others. first } \\
\text { priority should be to serve others, } \\
\text { not to promote their own agendas } \\
\text { over the good of their followers }\end{array}$ & $\begin{array}{l}\text { This intuitively appealing theory } \\
\text { take the positives from } \\
\text { Transformational theory, adds } \\
\text { a values orientation, and places } \\
\text { a strong emphasis on teamwork. } \\
\text { Key weakness is that it is largely } \\
\text { atheoretical, highly altruistic, and } \\
\text { not supported by empirical data. }\end{array}$ & $\begin{array}{l}\text { Aligns with healthcare and } \\
\text { professional ethics but does not } \\
\text { suit situations where quick } \\
\text { decisions are required. }\end{array}$ \\
\hline $\begin{array}{l}\text { Collective/Shared/ } \\
\text { Distributed Leadership } \\
\text { Approaches }^{97-103,140-142,169}\end{array}$ & $2000 s$ & $\begin{array}{l}\text { This approach argues the no one } \\
\text { individual is the ideal leader in all } \\
\text { situations or circumstances and } \\
\text { that leadership is diffuse } \\
\text { throughout the organisation. } \\
\text { Includes dispersed, collaborative, } \\
\text { collective, devolved, relational, } \\
\text { democratic, concurrent, and co- } \\
\text { operative approaches. } \\
\text { Boundaries have been somewhat } \\
\text { blurred by the range of different } \\
\text { terms employed by these plural } \\
\text { forms of leadership. }\end{array}$ & $\begin{array}{l}\text { Shared leadership has been } \\
\text { positively correlated with } \\
\text { increased team effectiveness and } \\
\text { organizational performance. } \\
\text { Critics of this approach cite the } \\
\text { lack of empirical methodological } \\
\text { rigour, measurement issues with } \\
\text { the construct and the } \\
\text { transferability or application in } \\
\text { different cultural settings }\end{array}$ & $\begin{array}{l}\text { Demonstrated applicability in } \\
\text { healthcare settings and has been } \\
\text { adopted by the NHS in the UK. } \\
\text { Needs further exploration in the } \\
\text { wider H\&HS context. }\end{array}$ \\
\hline Complexity Theory ${ }^{98,104-106}$ & $2000 s$ & $\begin{array}{l}\text { This theory focusses on leadership } \\
\text { as part of a complex system and } \\
\text { the inter-relationships between } \\
\text { patterns of behaviour, power } \\
\text { structures and networks of } \\
\text { relationships. }\end{array}$ & $\begin{array}{l}\text { Strength is that complexity theory } \\
\text { provides a framework in which } \\
\text { effective leadership can thrive in } \\
\text { dynamic environments. } \\
\text { Weakness is that there is little } \\
\text { consensus on when and in which } \\
\text { situations complex leadership } \\
\text { should be applied. }\end{array}$ & $\begin{array}{l}\text { Potential to inform due to the } \\
\text { complex and unpredictable } \\
\text { nature of H\&HS leadership but } \\
\text { requires further research }\end{array}$ \\
\hline
\end{tabular}

the potential to be abused as it is concerned with changing people's values. ${ }^{44,78,87}$

Authentic leadership theory, building on from transformational leadership theory, is based on the premise of being true to oneself and one's values and the leader acting from a position of high ethical standards and self-regulation to make a positive contribution in the world. ${ }^{13,88,89}$ Selfregulation has been described as the process through which authentic leaders align their values with their intentions and actions. ${ }^{90}$ Critics of authentic leadership theory cite that the theory is still formative and has not been substantiated; there is an overemphasis on person-centred factors and a lack of attention to context results in the continuation of the concept of an "ideal or heroic leader" and the perpetuation of bias in favour of white males for promotion to power positions in organizations. $^{44,91,92}$

Servant leadership, which originated in the seminal work of Greenleaf, is based on the premise that power is distributed to the followers and that leaders work to serve their followers for the purpose of achieving organizational goals. ${ }^{13,44,65,93}$ 
This theory is intuitively appealing with a people-orientated approach that places a strong emphasis on integrity, teamwork and building relationships. ${ }^{65,94} \mathrm{~A}$ strong criticism of servant leadership is that it is largely atheoretical restricted by its own limitations in research design and not supported by empirical data despite being promoted within a broad range of organizations. ${ }^{13,44,90,94-96}$

Since the 2000s, there has been a distinct shift away from the heroic models of leadership. The collective, distributed, or shared leadership approaches argue that no one individual is the ideal leader in all situations or circumstances and that leadership is diffuse throughout the organization. ${ }^{82,97-99}$ The locus of leadership is separated from the organizational hierarchy, and all team members, not just those with an overt management function, can take a leadership role. ${ }^{82,100-102}$ This approach seems counterintuitive to many of the leader-centric leadership theories previously discussed. With changing organizational structures, increased levels of complexity and diversity, and changing patterns of work, the limitations of traditional leadership models with their individualistic understanding of leadership are being questioned. ${ }^{82,100,102,103}$ Critics of this approach cite the lack of empirical methodological rigour, measurement issues with the construct and the transferability or application in different cultures. ${ }^{100,101}$

The application of complexity theory to leadership has moved the focus of research from an emphasis on the leader as an individual or the leader-follower relationship to a focus on leadership as part of a complex system and the interrelationships between patterns of behaviour, power structures and networks of relationships. ${ }^{13,86,104-106}$ The viability of this theory is still uncertain as some authors argue it is only a philosophical lens for exploring leadership in organizational studies. ${ }^{104,106}$ Belrhiti et al ${ }^{53}$ in their scoping review found that there is little consensus on when and in which situation complex leadership should be applied and the relationship between complexity leadership and organizational performance is an area where more empirical research is required.

Examining the historical evolution of leadership theories does provide some context in which to conceptualize leadership, but we should also look at other approaches to truly appreciate the complexity of these phenomena.

\section{Leadership vs Management: Same or Different?}

Another approach when trying to conceptualise leadership is to compare and contrast the practices of management and leadership. The terms leadership and management are often used interchangeably, which can lead to confusion, and there are calls from some researchers for making an important distinction between the two terms. ${ }^{13,44,82,86,107-109}$

Azad et $\mathrm{al}^{110}$ argue that leadership and management are a continuum of a single construct, but the majority of the papers in this scoping review assert that they are distinct concepts. Zaleznik $^{111}$ in his seminal article argues there is a clear distinction between managers and leaders. Managers focus on process interacting to establish strategies and make decisions, whereas leaders work in the opposite direction. He went on to identify that managers act to limit choices in the workplace, leaders develop new and fresh approaches to long-standing problems and open issues to new options. ${ }^{111} \mathrm{Katz}^{61}$ asserts that management is unidirectional, whereas leadership is multidirectional. This argument is supported by Kotter ${ }^{112}$ and Leonard, ${ }^{17}$ who say management is a set of well-known processes, like planning, budgeting, structuring jobs, staffing jobs, measuring performance and problem-solving, which help an organization to predictably do what it knows how to do well. Leadership, by contrast, is about setting the direction, aligning and motivating people, and creating the right culture for success. Management produces a degree of predictability and order. Leadership produces change. Marion and Uhl-Bien in their discussion of leadership in complex organizations differentiated the constructs as leadership being focussed on growth, fitness, innovation, and the future of organizations, whereas management is focussed on the nuts and bolts of detailed day-to-day operations. ${ }^{104}$

Jandaghi et $\mathrm{al}^{85}$ assert that leadership and management are not identical. Management is dependent on formal power to influence others, while leadership is a result of a social influence process. This view is supported by several authors who assert that leadership is a series of interaction processes where people influence one another and that leaders are identified by their acts not by an appointed position. ${ }^{55,107}$

Some authors argue that both are important for success, and the separation of the two functions - management without leadership and leadership without management may be seen as misleading and potentially harmful in practice. ${ }^{82,113-115}$ Each concept has some unique features; however, I would argue that leadership and management are distinct but complementary activities, but both are required for successful organizations.

\section{Power, Influence and Leadership}

Another approach to conceptualizing leadership is to examine the concept of power and its relationship to 
leadership and organizational outcomes. ${ }^{116-118}$ Early definitions of leadership focused on power "over" people, whereas later definitions focused on the ability to influence others. The "Five Forms of Power" research conducted by French and Raven in 1959 is one of the most influential theories of power that has been used to explain many of the phenomena of social influence and determine the sources of power that leaders use to influence others. ${ }^{119}$ The five forms of power have stood the test of time and remained constant for the study of power in organizations. ${ }^{118,120}$

Reward power is the most common type of power and is defined as power whose basis is the ability to reward. ${ }^{119}$ The assumption is that if you have the ability to reward team members with things like bonuses or promotions, you have the ability to command their attention. Coercive Power is the opposite of reward power and is based on the ability to take things away or punish. The assumption is that team members are willing to comply with the leaders directive for fear of punishment. As stated by Joullie et $\mathrm{al}^{121}$ coercion is not cooperation and is associated with resentment and negative organizational outcomes. ${ }^{118,122,123}$ Legitimate or Position Power comes from being appointed to a specific position. Within an organization, the leader occupies a particular position with the right to influence team members. ${ }^{118,119}$ Referent Power is the ability to influence others because they like and respect the individual and desire to become closely associated with them. ${ }^{118,119}$ This type of power is borne out of admiration of another and is associated with charismatic leadership. ${ }^{118}$ Expert power is achieved when a person finds themselves in a position of expertise based on their knowledge, skills, and experience. Credibility is acquired by having the right credentials. ${ }^{118,119}$ Most leaders use a combination of these types of power, depending on the leadership style used and the context in which leadership occurs.

\section{Leader versus Leadership}

When describing leadership, the terms leader and leadership are often used interchangeably, but it is important to make a clear distinction as this influences the approach the researcher may take. The leader is the individual person; leadership is the function this individual performs or an influential process. Leader development is one aspect of leadership development.

Leader development is intrapersonal with a focus on individual leaders and is often associated with formal roles within an organization. ${ }^{13}$ Leader development results as a function of purposeful investment in human capital. Specific examples of the type of intrapersonal competence associated with leader development initiatives include selfawareness (eg, emotional awareness, self-confidence), self-regulation (eg, self-control, trustworthiness, adaptability), and self-motivation (eg, commitment, initiative, optimism).${ }^{124}$ Leaders are individuals or groups that influence the direction of a system or organization. ${ }^{89}$

In contrast, leadership development is interpersonal and focused on enhancing leadership capacity associated with both formal and informal roles within groups and organizations. ${ }^{13}$ The primary emphasis in leadership development is on building social capital. Specific components of interpersonal competence include social awareness (eg, empathy, service orientation, and developing others) and social skills (eg, collaboration and cooperation, building bonds, and conflict management). ${ }^{124}$ Leadership is a complex process of influencing the creation, destruction, transformation, and distribution of information throughout the system, and enabling action in response to this information in a complex environment. ${ }^{89}$

The development of the intrapersonal capabilities serves as a foundation for the interpersonal capabilities, which also encompasses the interactions with team members and the context in which leadership occurs, and both are required to address leadership using a workforce development lens in the H\&HS sector.

\section{Discussion}

The first objective of this review was to identify a definition of leadership applicable to the H\&HS sector. The lack of a universal definition should not be a deterrent to proposing a definition. Some key components central to understanding this phenomenon are identified in this review, but to address the complexity of the sector, these components need to be bought together into one cohesive definition that can be used to advance empirical research and evaluation of leadership development pertinent to the H\&HS sector. Thus, the proposed definition of leadership in the context of H\&HS is a dynamic process that influences outcomes in specific contexts and stimulates and inspires others, through respectful two-way relationships, towards the achievement of desired goals.

This definition implies that:

1. Leadership is a dynamic process, not a personal quality. ${ }^{43,44,47,49,51}$ 
2. Leadership is characterised by the ability to influence outcomes, not authority or power. $^{43,44,49,116-118,120-122}$

3. Leadership is not management, but they are complementary processes. ${ }^{61,85,104,112}$

4. Leadership occurs in specific contexts. If the context changes, the process will be different. ${ }^{50,70,125}$

5. Leadership requires respectful relationships with others - one leading the other, or both mutually leading one another - it is not a solo pursuit. $^{44,60,86,108,126}$

6. Leadership involves the achievement of goals. ${ }^{44,50}$

The second objective of this review was to identify and describe the theories and approaches to leadership and the relevance to H\&HS sector workforce development. The results from this review demonstrate overwhelmingly that the majority of research in the field of leadership has been conducted in business settings in Western contexts, and mainstream leadership theories offer mixed results for the H\&HS sector. Despite the extensive research into leadership in healthcare, a central problem is that much of this research is predominantly focused on the narrow disciplinary or workforce fields of the nursing and medical professions in hospitals and acute care settings. Relatively little scholarship has focused on the broader H\&HS sector.

Of the theories presented, three are cited as showing the potential to inform leadership in the H\&HS sector. Transformational leadership features heavily in healthcare leadership ${ }^{87,98,114}$ and has been associated with high performing teams and improved patient care; ${ }^{127,128}$ Magnet nursing organizations; ${ }^{129}$ and a reduction in nursing staff turnover. ${ }^{130}$ There is some evidence that transformational leadership has been shown to be effective in the human and social services sector ${ }^{131,132}$ and in particular with the social work profession. ${ }^{133,134}$

Authentic leadership with its focus on ethical behaviour and trusting leader-follower relationships has been cited as being particularly applicable to healthcare settings by a number of studies. ${ }^{135,136}$ Shirey ${ }^{137}$ found a positive correlation between authentic leadership and health work environments in acute care hospitals. Coxen et al ${ }^{138}$ found that authentic leadership had a significant influence on trust in public healthcare organizations. Malila et al ${ }^{139}$ revealed that whilst the theory demonstrates potential in the healthcare setting, the current research has not been comprehensive and identified a number of research gaps including the need to test in a variety of populations, settings and cultures.

While collective or shared leadership was adopted as a key strand of policy by the National Health Service in the UK, the focus has been on the medical and nursing professions in acute care settings. ${ }^{140-143}$ Antecedents for successful shared leadership have been identified as employee commitment, staff autonomy, managerial guidance, collaborative decision-making, a culture of innovation and a shared organizational vision. ${ }^{103}$ Whilst collective or shared leadership has been found unsuitable where tasks are routine or employees have low levels of autonomy, this is not the case in healthcare, which recognises that care and support are provided in complex systems. $^{82,98,103}$ The review could not identify evidence of this leadership approach being explored in the broader H\&HS sector.

Exploration of the use of power and leadership in the H\&HS sector reveals again that the medical profession and hospitals dominate the research. ${ }^{116,117}$ Gabel $^{117}$ identifies the bases of power available to medical professionals and discusses the application in medical practice but fails to consider the broader system or other professions. A quantitative study undertaken by Havold and Havold $^{144}$ found that legitimate, referent and reward power had a positive influence on trust whilst coercive power had a negative influence in hospitals. Saxena et $\mathrm{al}^{116}$ acknowledge that healthcare requires collaborative leadership but still sees physician leaders as those who will lead diverse groups of healthcare workers.

The focus on the medical profession was evident from Bottles, ${ }^{145}$ who stated that healthcare leadership has failed miserably when judged by the production of intended effects and that "physician executives must provide leadership"145 and Swanwick and McKimm, ${ }^{82}$ who argue that leadership is the responsibility of doctors. Berghout et $\mathrm{al}^{24}$ conducted a systematic review focussed exclusively on medical leadership in hospital settings. Keijser et $\mathrm{al}^{146}$ also focused on medical professionals in developing their leadership competency framework. Gordon et al ${ }^{147}$ conducted a qualitative study purported to focus on healthcare leadership but interviews were only conducted with medical trainees resulting in a strong medical emphasis. The authors did acknowledge that future research should consider broadening the approach to include the wider interprofessional team but failed to discuss the broader H\&HS sector. 
A significant number of papers examined leadership as a fundamental skill of nursing practice, ${ }^{11,55,79,148-152}$ while Kan and Parry ${ }^{153}$ used grounded theory to generate a theory to explain nursing leadership in New Zealand hospital settings. Malila et al, ${ }^{139}$ in undertaking a scoping review of authentic leadership in healthcare, identified nurses as the most common study population, while hospitals and acute healthcare settings were most frequent. The authors identified the need for greater diversity in study population, setting, organization and geographical origins. Mianda and Voce ${ }^{154}$ limited their literature review to clinical leadership for frontline healthcare workers. Nelson-Brantley and Ford ${ }^{155}$ argue that nurses should be leading change and redesign in health systems. None of these authors consider the broader H\&HS sector.

Professions that have identified a paucity of research related to leadership includes radiography; ${ }^{113}$ social work; ${ }^{23}$ psychology ${ }^{156}$ and pharmacy ${ }^{157}$ irrespective of the practice setting. The lack of a robust empirical foundation for leadership in the human service sector is an identifying challenge. ${ }^{27,158}$ Smith et $\mathrm{al}^{3}$ noted that there are significant structural and cultural differences that need to be acknowledged between health and social care organizations.

The final objective of this scoping review was to provide a preliminary analysis of the potential size and scope of available research literature to inform ongoing research. This review demonstrates that there is limited high-quality research available regarding leadership approaches that inform broader H\&HS sector workforce development and identifies prominent gaps in our understanding of leadership in the sector. This review demonstrates that there is a significant body of research dedicated to healthcare leadership, predominantly undertaken by the medical and nursing professions in acute care settings, but there is a lack of evidence that any of these approaches may be transferrable to other H\&HS contexts and professions.

The review raises more questions that need to be answered. We need to understand how leadership is developed within the broader H\&HS sector. We need to understand what should be included (the interventions or initiatives) in leadership development programs to enhance workforce capacity in the H\&HS sector. We need to understand how we know what is taught is effective and transferable to the workplace.

\section{Limitations}

Acknowledgement must be given to the inherent limitations specific to a scoping review, including the absence of quality appraisal, potential interpretation bias and the balance between comprehensiveness and feasibility. ${ }^{30,33,36}$ Only one person conducted the literature review, so the conclusions, including themes and definitions of leadership, were not subject to any additional assessment. In order to at least partially validate the results, an additional analysis or review by one or more individuals is warranted. ${ }^{23}$

\section{Conclusion}

This review demonstrates that leadership is a multifaceted, multi-contextual phenomenon that can be defined in multiple ways. Despite prolific volumes of the literature on leadership, no theory or approach so far has provided a satisfactory explanation of leadership in the health and human service sector. This review has provided a definition of leadership for the H\&HS sector.

The need for rigorous research on leadership to inform workforce development in the broad H\&HS sector is evident. This review demonstrates that there is a paucity of leadership development research specific to the broader H\&HS sector. One way to investigate leadership development is through the lens of workforce development. We need to understand what are the knowledge, skills and capabilities that enable individual health and human service practitioners to develop as more effective leaders in the diverse environments of the sector. ${ }^{159}$ The definition of leadership proposed in this review may inform further research in this area.

\section{Data Sharing Statement}

The data that support this study will be shared upon reasonable request to the corresponding author.

\section{Acknowledgments}

The author acknowledges the support and guidance received from her supervisory team and colleagues at the University of Tasmania including Professor Roger Hughes, Dr Pieter van Dam, Dr Elaine Hart, Associate Professor Nicola Stevens, and Professor Adele Holloway.

\section{Disclosure}

The author declares that there are no competing interests in this work.

\section{References}

1. Joubert L, Boyce R, McKinnon K, Posenelli S, McKeever J. Strategies for Allied Health Leadership Development: Enhancing Quality, Safety and Productivity. Melbourne, Victoria, Australia: Department of Health and Human Services; 2016.

2. Smith T, Fowler-Davis S, Nancarrow S, Ariss SMB, Enderby P. Leadership in interprofessional health and social care teams: a literature review. Leadersh Health Serv. 2018;31(4):452-467. doi:10.1108/LHS-06-2016-0026 
3. Smith T, Fowler Davis S, Nancarrow S, Ariss S, Enderby P. Towards a theoretical framework for integrated team leadership (igtl). J Interprof Care. 2020;34(6):726-736. doi:10.1080/ 13561820.2019.1676209

4. Department of Health and Human Services. Ceo Leadership Capability Framework. Melbourne, Australia: Victorian Government; 2019.

5. Figueroa CA, Harrison R, Chauhan A, Meyer L. Priorities and challenges for health leadership and workforce management globally: a rapid review. BMC Health Serv Res. 2019;19(1):239. doi:10.1186/s12913-019-4080-7

6. Health Workforce Australia. Australian Health Leadership Framework. Adelaide, Australia: Health LEADS Australia; 2012.

7. Forsyth L Unleashing a new generation of human services leaders. KPMG Insights. Sydney, Australia: KPMG International; 2017.

8. Hussain A, Ashcroft R. Social work leadership competencies in health and mental healthcare: a scoping review protocol. $B M J$ Open. 2020;10(10):e038790. doi:10.1136/bmjopen-2020-038790

9. Lacerenza CN, Reyes DL, Marlow SL, Joseph DL. Leadership training design, delivery, and implementation: a meta-analysis. J Appl Psychol. 2017;102(12):1686-1718. doi:10.1037/ap10000241

10. Aged Care Workforce Strategy. A Matter of Care. Canberra, Australia: Department of Health; 2018.

11. Miles JM, Scott ES. A new leadership development model for nursing education. $J$ Prof Nurs. 2019;35(1):5-11. doi:10.1016/j. profnurs.2018.09.009

12. Bennis W, Nanus N. Leaders: The Strategies for Taking Charge. New York, USA: Harper and Row; 1985.

13. Ardichvili A, Manderscheid SV. Emerging practices in leadership development: an introduction. Adv Dev Hum Res. 2008;10 (5):619-631. doi:10.1177/1523422308321718

14. Bass BM. Leadership and Performance Beyond Expectations. New York, USA: The Free Press; 1985.

15. Avery G. Understanding Leadership: Paradigms and Cases. Australia: Sage Publications; 2004.

16. Conger J, Hollenbeck GP. What is the character of research on leadership character? Consult Psychol J. 2010;62(4):311-316. doi: $10.1037 / \mathrm{a} 0022358$

17. Leonard HS. A teachable approach to leadership. Consult Psychol J. 2017;69(4):243-266. doi:10.1037/cpb0000096

18. Flood PS. Instructional leadership: it's not just for principals anymore. Middle Sch J. 2004;36(1):54-60. doi:10.1080/ 00940771.2004.11461467

19. Sutherland J, Cameron R Employing phenomenology to highlight the richness of the leadership experience. Paper presented at: Proceedings of the European Conference on e-Learning; 2015; Europe.

20. Johnson D, Bainbridge P, Hazard W. Understanding a new model of leadership. $J$ Paramed Pract. 2013;5(12):686-690. doi:10.12968/jpar.2013.5.12.686

21. Chatterjee R, Suy R, Yen Y, Chhay L. Literature review on leadership in healthcare management. $J$ Soc Sci Stud. 2018;5(1):38-47.

22. Antill C. Rocking the boat: the link between transformational leadership and advocacy. $\mathrm{Br} J$ Healthcare Assistants. 2015;9 (2):93-99. doi:10.12968/bjha.2015.9.2.93

23. Peters SC. Defining social work leadership: a theoretical and conceptual review and analysis. J Soc Work Pract. 2018;32 (1):31-44. doi:10.1080/02650533.2017.1300877

24. Berghout MA, Fabbricotti IN, Buljac-Samardzic M, Hilders CGJM. Medical leaders or masters? - a systematic review of medical leadership in hospital settings. PLoS One. 2017;12 (9):24. doi:10.1371/journal.pone.0184522

25. Creswell JW, Creswell JD. Research Design: Qualitative, Quantitative and Mixed Method Approaches. 5th ed. Thousand Oaks, California, USA: Sage Publishing; 2018.

26. Suddaby R. Construct clarity in theories of management and organization. Acad Manage J. 2010;35(3):346-357.
27. Healy K, Lonne B. The Social Work and Human Services Workforce: Report from a National Study of Education, Training and Workforce Needs. Strawberry Hills, NSW, Australia: Australian Learning and Teaching Council; 2010.

28. Woodside M, McClam T. Introduction to Human Services. 8th ed. Stamford, USA: Cengage Learning; 2015.

29. World Health Organization. Everybody's Business: Strengthening Health Systems to Improve Health Outcomes. Geneva, Switzerland: World Health Organization; 2007.

30. Grant MJ, Booth A. A typology of reviews: an analysis of 14 review types and associated methodologies. Health Info Libr J. 2009;26:91-108. doi:10.1111/j.1471-1842.2009.00848.x

31. Sutton A, Clowes M, Preston L, Booth A. Meeting the review family: exploring review types and associated information retrieval requirements. Health Inf Libr J. 2019;36:202-222. doi:10.1111/hir.12276

32. Winchester CL, Salji M. Writing a literature review. J Clin Urol. 2016;9(5):308-312. doi:10.1177/2051415816650133

33. Joanna Briggs Institute. Joanna Briggs Institute Reviewers Manual. Australia: The Joanna Briggs Institute; 2015.

34. Arksey H, O'Malley L. Scoping studies: towards a methodological framework. Int J Soc Res Methodol. 2005;8 (1):19-32. doi:10.1080/1364557032000119616

35. Levac D, Colquhoun H, O'Brien KK. Scoping studies: advancing the methodology. Implement Sci. 2010;5(1):69. doi:10.1186/17485908-5-69

36. Peters MDJ, Marnie C, Tricco AC, et al. Updated methodological guidance for the conduct of scoping reviews. JBI Evid Synth. 2020;18(10):2119-2126. doi:10.11124/JBIES-20-00167

37. Pawliuk C, Brown HL, Widger K, et al. Optimising the process for conducting scoping reviews. BMJ Evid Based Med. 2020. doi:10.1136/bmjebm-2020-111452

38. Khalil H, Peters MDJ, Tricco AC, et al. Guidance to conducting high quality scoping reviews. $J$ Clin Epidemiol. 2020;130:156-160.

39. Aveyard H. Doing a Literature Review in Health and Social Care: A Practical Guide. 2nd ed. Berkshire, UK: Open University Press; 2011.

40. Hagen-Zanker J, Mallett R. How to Do a Rigorous, EvidenceFocused Literature Review on International Development: A Guidance Note. London, UK: Overseas Development Institute; 2013.

41. Tricco AC, Lillie E, Zarin W, et al. Prisma extension for scoping reviews (prismascr): checklist and explanation. Ann Intern Med. 2018;169:467-473. doi:10.7326/M18-0850

42. Moher D, Liberati A, Tetzlaff J, Altman DG; The PRISMA Group. Preferred reporting items for systematic reviews and meta-analyses: the prisma statement. PLoS Med. 2009;6(7): e1000097. doi:10.1371/journal.pmed.1000097

43. Yukl G. Leadership in Organizations. 8th ed. London, UK: Pearson; 2012.

44. Northouse PG. Leadership: Theory and Practice. 8th ed. Thousand Oaks, California, USA: Sage Publications; 2018.

45. Van Dick R, Monzani L. Positive leadership in organizations. Psychology. 2020;23. doi:10.1093/acrefore/9780190236557.013.814

46. Burns JM. Leadership. New York, USA: Harper and Row; 1978

47. Yukl G. Managerial leadership: a review of theory and research. $J$ Manag. 1989;15(2):251-289. doi:10.1177/01492063890150 0207

48. Bass BM. Bass and Stogdill's Handbook of Leadership: Theory, Research, and Managerial Applications. 3rd ed. New York, USA: The Free Press; 1990.

49. Rost JC. Leadership for the Twenty-First Century. New York: Praeger; 1991.

50. Vroom VH, Jago AG. The role of the situation in leadership. Am Psychol. 2007;62(1):17-24. doi:10.1037/0003-066X.62.1.17 
51. Branchini AZ. Leadership of the Pioneers of Nursing Informatics: A Multiple Case Study Analysis. Connecticut, USA: Nursing, University of Connecticut; 2012.

52. Smith P, Cockburn T. Leadership in the digital age: rhythms and the beat of change. In: Smith PC, editor. Impact of Emerging Digital Technologies on Leadership in Global Business. USA: IGI Global; 2014.

53. Belrhiti Z, Nebot Giralt A, Marchal B. Complex leadership in healthcare: a scoping review. Int J Health Policy Manag. 2018;7 (12):1073-1084. doi:10.15171/ijhpm.2018.75

54. Bass BM, Bass R. The Bass Handbook of Leadership: Theory, Research and Managerial Applications. 4th ed. New York, USA: The Free Press; 2008.

55. Curtis EA, de Vries J, Sheerin FK. Developing leadership in nursing: exploring core factors. Br J Nurs. 2011;20(5):306-309. doi:10.12968/bjon.2011.20.5.306

56. Park S, Jeong S, Jang S, Yoon SW, Lim DH. Critical review of global leadership literature: toward an integrative global leadership framework. Hum Resour Dev Rev. 2018;17(1):95-120. doi: $10.1177 / 1534484317749030$

57. University of Cambridge. Global definitions of leadership and theories of leadership development. SB Communications Weekly; 2017:1. Available from: http://search.ebscohost.com/ login.aspx?direct=true $\& \mathrm{db}=$ bsu\&AN=124166191\&site=ehostlive. Accessed October 15, 2021.

58. Zaccaro SJ. Trait-based perspectives of leadership. Am Psychol. 2007;62(1):6-16. doi:10.1037/0003-066X.62.1.6

59. Gooty J, Connelly S, Griffith J, Gupta A. Leadership, affect and emotions: a state of the science review. Leadersh $Q$. 2010;21:979-1004. doi:10.1016/j.leaqua.2010.10.005

60. Chobanuk J, James K. Leadership special interest group: what is leadership? Can Oncol Nurs J. 2015;25(1):114-117.

61. Katz RL. Skills of an Effective Administrator. USA: Harvard Business Review Press; 1955.

62. Mumford MD, Zaccaro SJ, Harding FD, Jacobs TO, Fleishman EA. Leadership skills for a changing world: solving complex social problems. Leadersh Q. 2000;11(1):11-35. doi:10.1016/S1048-9843(99)00041-7

63. Mumford TV, Campion MA, Morgeson FP. The leadership skills strataplex: leadership skill requirements across organizational levels. Leadersh Q. 2007;18(2):154-166. doi:10.1016/j.leaqua.2007.01.005

64. Blake RR, Mouton J. The Managerial Grid III: The Key to Leadership Excellence. Houston, Texas, USA: Gulf Publishing; 1985.

65. Marques J. Awakened leadership in action: a comparison of three exceptional business leaders. J Manag Dev. 2008;27(8):812-823. doi: $10.1108 / 02621710810895640$

66. Xhelilaj E, Sakaj B. A review of leadership behaviour of maritime officers in international shipping. Sci J Marit Res. 2018;32 (1):76-79.

67. Chukwusa J. Autocratic leadership style: obstacle to success in academic libraries. Libr Philos Pract. 2019. Available from: http://digitalcommons.unl.edu/libphilprac/2019. Accessed October 22, 2021.

68. Yang I. Positive effects of laissez-faire leadership: conceptual exploration. $J$ Manag Dev. 2015;34(10):1246-1261. doi:10.1108/JMD-02-2015-0016

69. Hersey P, Blanchard KH. Life cycle theory of leadership. Train Dev J. 1969;23(5):26-34.

70. Lorsch JW. A contingency theory of leadership. In: Nohria NaK R, editor. Handbook of Leadership Theory and Practice. USA: Harvard Business Press; 2010:411-432.

71. Fiedler F. The effects of leadership training and experience: a contingency model interpretation. Adm Sci Q. 1972;17 (4):453-470. doi:10.2307/2393826
72. House RJ. Path-goal theory of leadership: lessons, legacy, and a reformulated theory. Leadersh Q. 1996;7(3):323-352. doi:10.1016/S1048-9843(96)90024-7

73. House RJ, Mitchell TR. Path-Goal Theory of Leadership. Washington, Seattle, USA: University of Washington; 1975.

74. Jermier JM. The path-goal theory of leadership: a subtextual analysis. Leadersh Q. 1996;7(3):311. doi:10.1016/S10489843(96) $90022-3$

75. Martin J. Library leadership your way. Ser Libr. 2020;1-8. doi:10.1080/0361526X.2020.1707022

76. Hunt TJ. Leader-member exchange relationships in health information management. Perspect Health Inf Manag. 2014;11:1d.

77. Gottfredson RK, Wright SL, Heaphy ED. A critique of the leader-member exchange construct: back to square one. Leadersh Q. 2020;17. doi:10.1016/j.leaqua.2020.101385

78. van Knippenberg D, Sitkin SB. A critical assessment of charismatic - transformational leadership research: back to the drawing board? Acad Manag Ann. 2013;7(1):1-60. doi:10.1080/ 19416520.2013 .759433

79. Scully NJ. Leadership in nursing: the importance of recognising inherent values and attributes to secure a positive future for the profession. Collegian. 2015;22(4):439-444. doi:10.1016/j. colegn.2014.09.004

80. Levine KJ, Muenchen RA, Brooks AM. Measuring transformational and charismatic leadership: why isn't charisma measured? Commun Monogr. 2010;77(4):576-591. doi:10.1080/ 03637751.2010 .499368

81. Casida J, Parker J. Staff nurses perceptions of nurse manager leadership styles. J Nurs Manag. 2011;19:478-486. doi:10.1111/ j.1365-2834.2011.01252.x

82. Swanwick T, McKimm J. What is clinical leadership ... and why is it important? Clin Teach. 2011;8(1):22-26. doi:10.1111/j.1743498X.2010.00423.x

83. Folta SC, Seguin RA, Ackerman J, Nelson ME. A qualitative study of leadership characteristics among women who catalyze positive community change. BMC Public Health. 2012;12(1):12. doi:10.1186/1471-2458-12-383

84. Bass BM. Two decades of research and development in transformational leadership. Eur J Work Organ Psychol. 1999;8(1):9-32. doi:10.1080/135943299398410

85. Jandaghi G, Matin HZ, Farjami A. Comparing transformational leadership in successful and unsuccessful companies. $J$ Int Soc Res. 2009;1(6):356-372.

86. Kouzes JM, Posner BZ. The Leadership Challenge. San Franscisco, USA: Jossey-Bass; 1995.

87. Trottier T, Van Wart M, Wang X. Examining the nature and significance of leadership in government organizations. Public Adm Rev. 2008;68(2):319-333. doi:10.1111/j.1540-6210.2007.00865.x

88. Ilies RT, Morgeson FP, Nahrgang JD. Authentic leadership and eudaemonic well-being: understanding leader-follower outcomes. Leadersh Q. 2005;16:373-394. doi:10.1016/j.leaqua.2005.03.002

89. Livingston D, Lusin J A prescriptive hybrid model of leadership: complexity leadership theory and authentic leadership theory. Proceedings of the European Conference on Management, Leadership \& Governance; 2009:102-109. Available from: http:// search.ebscohost.com/login.aspx?direct $=$ true $\& \mathrm{db}=\mathrm{bsu} \& A N=$ 48918402\&site=ehost-live. Accessed October 15, 2021.

90. Avolio BJ, Gardner WL. Authentic leadership development: getting to the root of positive forms of leadership. Leadersh $Q$. 2005;16:315-338. doi:10.1016/j.leaqua.2005.03.001

91. Gardiner R. Gender, authenticity and leadership: thinking with arendt. Leadership. 2016;12(5):632-637. doi:10.1177/ 1742715015583623

92. Fox-Kirk W. Viewing authentic leadership through a bourdieusian lens: understanding gender and leadership as social action. $A d v$ Dev Hum Res. 2017;19(4):439-453. doi:10.1177/1523422317728939 
93. Greenleaf RK. Servant: retrospect and prospect. In: Spears LC, editor. The Power of Servant Leadership. Oakland, California, USA: Berrett-Koehler Publishers Inc; 1998:17-59.

94. Dutta S, Khatri P. Servant leadership and positive organizational behaviour: the road ahead to reduce employees' turnover intentions. Horiz. 2017;25(1):60-82. doi:10.1108/OTH-06-2016-0029

95. Eva N, Robin M, Sendjaya S, van Dierendonck D, Liden RC. Servant leadership: a systematic review and call for future research. Leadersh $Q$. 2019;30(1):111-132. doi:10.1016/j. leaqua.2018.07.004

96. Parris DL, Peachey JW. A systematic literature review of servant leadership theory in organizational contexts. $J$ Bus Ethics. 2013;113(3):377-393. doi:10.1007/s10551-012-1322-6

97. Avolio BJ, Walumbwa FO, Weber TJ. Leadership: current theories, research and future directions. Annu Rev Psychol. 2009;60:421-449. doi:10.1146/annurev.psych.60.110707.163621

98. West M, Armit K, Lowenthal L, Eckhert R, West T, Lee A. Leadership and Leadership Development in Health Care: The Evidence Base. London, UK: The Kings Fund; 2015.

99. De Brún A, Anjara S, Cunningham U, et al. The collective leadership for safety culture (co-lead) team intervention to promote teamwork and patient safety. Int $J$ Environ Res Public Health. 2020;17(22):8673. doi:10.3390/ijerph17228673

100. Hairon S, Goh JW. Pursuing the elusive construct of distributed leadership: is the search over? Educ Manag Adm Leadersh. 2015;43(5):693-718. doi:10.1177/1741143214535745

101. Harris A. Teacher leadership as distributed leadership: heresy, fantasy or possibility? Sch Leadersh Manag. 2003;23 (3):313-324. doi:10.1080/1363243032000112801

102. Harris A. Distributed leadership: friend or foe? Educ Manag Adm Leadersh. 2013;41(5):545-554. doi:10.1177/1741143213497635

103. Sweeney A, Clarke N, Higgs M. Shared leadership in commercial organizations: a systematic review of definitions, theoretical frameworks and organizational outcomes. Int J Manag Rev. 2019;21 (1):115-136. doi:10.1111/ijmr.12181

104. Marion R, Uhl-Bien M. Leadership in complex organizations. Leadersh Q. 2001;12(4):389-418. doi:10.1016/S1048-9843(01) 00092-3

105. Schneider M, Somers M. Organizations as complex adaptive systems: implications of complexity theory for leadership research. Leadersh $Q$. 2006;17:351-365. doi:10.1016/j.leaqua.2006.04.006

106. Rosenhead J, Franco LA, Grint K, Friedland B. Complexity theory and leadership practice: a review, a critique, and some recommendations. Leadersh Q. 2019;30(5):101304. doi:10.1016/ j.leaqua.2019.07.002

107. Karp T. Studying subtle acts of leadership. Leadership. 2013;9 (1):3-22. doi:10.1177/1742715012447007

108. Yang R. Examining the distinct concepts of "leadership" and "management" and the relationship between them. Adv Soc Sci Educ Hum Res. 2016;85:1168-1171.

109. Limb M. How does leadership differ from management in medicine? Br Med J. 2016;352:1-2.

110. Azad N, Anderson HG Jr, Brooks A, et al. Leadership and management are one and the same. Am J Pharm Educ. 2017;81 (6):102. doi:10.5688/ajpe816102

111. Zaleznik A. Managers and leaders: are they different? Harv Bus Rev. 1977;55(5):67-80.

112. Kotter J. What leaders do. In: Review HB, editor. Harvard Business review 10 Must Reads: On Leadership for Healthcare. Boston, USA: Harvard Business Press; 1990:37-56.

113. Hendry JA. Are radiography lecturers, leaders? Radiography. 2013;19(3):251-258. doi:10.1016/j.radi.2013.01.004

114. West M, West T. Leadership in healthcare: a review of the evidence. Health Manage Forum. 2015;15(2):1-5.

115. Cangemi JP, Kowalski CJ, Khan KH. Leadership Behaviours. New York, USA: University Press of America; 1998.
116. Saxena A, Meschino D, Hazelton L, et al. Power and physician leadership. BMJ Leader. 2019;3:92-98. doi:10.1136/leader-2019000139

117. Gabel S. Power, leadership and transformation: the doctor's potential for influence. Med Educ. 2012;46:1152-1160. doi:10.1111/medu. 12036

118. Lunenburg FC. Power and leadership: an influence process. Int J Manag Bus Adm. 2012;15(1):1-9.

119. French JRP, Raven B. The bases of social power. In: Cartwright D, editor. Studies in Social Power. Ann Arbor, Michigan, USA: Institute for Social Research; 1959:259-269.

120. Peyton T, Zigarmi D, Fowler SN. Examining the relationship between leaders' power use, followers' motivational outlooks, and followers' work intentions. Front Psychol. 2019;9:1-20. doi:10.3389/fpsyg.2018.02620

121. Joullié J-E, Gould AM, Spillane R, Luc S. The language of power and authority in leadership. Leadersh $Q .2020 ; 101491$. doi:10.1016/j.leaqua.2020.101491

122. Lucas JW, Baxter AR. Power, influence, and diversity in organizations. Ann Am Acad Pol Soc Sci. 2012;639(1):49-70. doi:10.1177/0002716211420231

123. Faiz N. Impact of manager's reward power and coercive power on employee's job satisfaction: a comparative study of public and private sector. Int J Manag Bus Res. 2013;3(4):383-392.

124. Day DV, Fleenor JW, Atwater LE, Sturm RE, McKee RA. Advances in leader and leadership development: a review of 25 years of research and theory. Leadersh Q. 2014;25(1):63-82. doi:10.1016/j.leaqua.2013.11.004

125. Murphy SE, Blyth D, Fiedler F. Cognitive Resource Theory and the Utilization of the Leader's and Group Members' Technical Competence. Seattle, Washington, USA: U.S. Army Research Institute for the Behavioral and Social Sciences; 1995.

126. Carter DR, DeChurch LA, Braun MT, Contractor NS. Social network approaches to leadership: an integrative conceptual review. J Appl Psychol. 2015;100(3):597-622. doi:10.1037/ a0038922

127. Fischer SA. Transformational leadership in nursing: a concept analysis. $J$ Adv Nurs. 2016;72(11):2644-2653. doi:10.1111/ jan. 13049

128. Fischer SA. Developing nurses' transformational leadership skills. Nurs Stand. 2017;31(51):54-61. doi:10.7748/ns.2017. e10857

129. Sherman RO, Habel M. Transformational leadership: a growing promise for nursing. Continuing Education; 2015. Available from: https://resources.nurse.com/magnet-hospitals-transformationalleadership. Accessed 2021.

130. Suliman M, Aljezawi M, Almansi S, Musa A, Alazam M, Ta'an WF. Effect of nurse managers' leadership styles on predicted nurse turnover. Nurs Manag. 2020;27(5):20-25. doi:10.7748/nm.2020.e1956

131. Middleton J, Harvey S, Esaki N. Transformational leadership and organizational change: how do leaders approach trauma-informed organizational change ... twice? Fam Soc. 2015;96(3):155-163. doi:10.1606/1044-3894.2015.96.21

132. Tafvelin S. The Transformational Leadership Process: Antecedents, Mechanisms, and Outcomes in the Social Services. Umea, Sweden: Department of Psychology, Umea University; 2013.

133. Mary NL. Transformational leadership in human service organizations. Adm Soc Work. 2005;29(2):105-118. doi:10.1300/ J147v29n02 07

134. Zhang H, Liu Z, Wang Y. How transformational leadership positively impacts organizational citizenship behavior in successful Chinese social work service organizations. Nonprofit Manag Leadersh. 2020;30(3):467-485. doi:10.1002/ $\mathrm{nml} .21391$ 
135. Alilyyani B, Wong CA, Cummings G. Antecedents, mediators, and outcomes of authentic leadership in healthcare: a systematic review. Int $J$ Nurs Stud. 2018;83:34-64. doi:10.1016/j. ijnurstu.2018.04.001

136. Wong CA, Giallonardo M. Authentic leadership and nurse-assessed adverse patient outcomes. J Nurs Manag. 2013;21(5):740-752. doi:10.1111/jonm.12075

137. Shirey MR. Authentic leadership, organizational culture, and healthy work environments. Crit Care Nurs Q. 2009;32 (3):189-198. doi:10.1097/CNQ.0b013e3181ab91db

138. Coxen L, van der Vaart L, Stander MW. Authentic leadership and organisational citizenship behaviour in the public health care sector: the role of workplace trust. S Afr J Ind Psychol. 2016;42 (1):1-13.

139. Malila N, Lunkka N, Suhonen M. Authentic leadership in healthcare: a scoping review. Leadersh Health Serv. 2018;31 (1):129-146. doi:10.1108/LHS-02-2017-0007

140. Willocks SG, Wibberley G. Exploring a shared leadership perspective for nhs doctors. Leadersh Health Serv. 2015;28 (4):345-355. doi:10.1108/LHS-08-2014-0060

141. Aufegger L, Alabi M, Darzi A, Bicknell C. Sharing leadership: current attitudes, barriers and needs of clinical and non-clinical managers in uk's integrated care system. BMJ Leader. 2020;4 (3):128-134. doi:10.1136/leader-2020-000228

142. Nightingale A. Implementing collective leadership in healthcare organisations. Nurs Stand. 2020;35(5):53-57. doi:10.7748/ns.2020. e11448

143. Eckert R, West M, Altman DG, Steward K, Pasmore B. Delivering a Collective Leadership Strategy for Health Care. London, UK: The King's Fund; 2014.

144. Håvold JI, Håvold OK. Power, trust and motivation in hospitals. Leadersh Health Serv. 2019;32(2):195-211. doi:10.1108/LHS-032018-0023

145. Bottles K. Leading in a chaotic health care environment. Physician Exec. 2000;26:56-61.

146. Keijser WA, Handgraaf HJM, Isfordink LM, et al. Development of a national medical leadership competency framework: the Dutch approach. BMC Med Educ. 2019;19(1):441. doi:10.1186/ s12909-019-1800-y

147. Gordon LJ, Rees CE, Ker JS, Cleland J. Dimensions, discourses and differences: trainees conceptualising health care leadership and followership. Med Educ. 2015;49(12):1248-1262. doi:10.1111/ medu. 12832

148. Milton CL. Transparency in nursing leadership: a chosen ethic. Nurs Sci Q. 2009;22(1):23-26. doi:10.1177/ 0894318408329159

149. Pearson A, Laschinger H, Porritt K, Tucker D, Long L. Comprehensive systematic review of evidence on developing and sustaining nursing leadership that fosters a healthy work environment in healthcare. JBI Libr Syst Rev. 2004;5 (5):279-343

150. Stanley D. Recognizing and defining clincial nurse leaders. Br J Nurs. 2006;15(2):108-111. doi:10.12968/bjon.2006.15.2.20373

151. Leclerc L, Kennedy K, Campis S. Human-centered leadership in health care: an idea that's time has come. Nurs Adm Q. 2020;44 (2):117-126. doi:10.1097/naq.0000000000000409
152. Fleming ML. Nursing Home Leadership: Experience and Perceptions of Directors of Nursing. Ann Arbor, MI, USA: School of Nursing, University of California, San Francisco; 2007.

153. Kan MM, Parry KW. Identifying paradox: a grounded theory of leadership in overcoming resistance to change. Leadersh $Q$. 2004; 15:467-491.

154. Mianda S, Voce A. Developing and evaluating clinical leadership interventions for frontline healthcare providers: a review of the literature. BMC Health Serv Res. 2018;18:1-15. doi:10.1186/s12913-018-3561-4

155. Nelson-Brantley HV, Ford DJ. Leading change: a concept analysis. J Adv Nurs. 2017;73(4):834-846. doi:10.1111/jan.13223

156. Clements CB. Training in human service management for future practitioner-managers. Prof Psychol Res Pr. 1992;23(2):146-150. doi:10.1037/0735-7028.23.2.146

157. Reed BN, Klutts AM, Mattingly TJ 2nd. A systematic review of leadership definitions, competencies, and assessment methods in pharmacy education. Am J Pharm Educ. 2019;83(9):7520. doi:10.5688/ajpe7520

158. Haworth S, Miller R, Schaub J. Leadership in Social Work: And Can It Learn from Clinical Healthcare? Birmingham, UK: University of Birmingham; 2018.

159. Day DV, Dragoni L. Leadership development: an outcome-oriented review based on time and levels of analyses. Annu Rev Organ Psychol Organ Behav. 2015;2(1):133-156. doi:10.1146/annurev-orgpsych-032414-111328

160. Spector BA. Carlyle, Freud, and the great man theory more fully considered. Leadership. 2015;12(2):250-260. doi:10.1177/ 1742715015571392

161. Stogdill RM. Personal factors associated with leadership: a survey of the literature. J Psychol. 1948;25(1):35-71. doi:10.1080/ 00223980.1948 .9917362

162. Fleishman EA, Mumford MD, Zaccaro SJ, Levin KY, Korotkin AL, Hein MB. Taxonomic efforts in the description of leader behavior: a synthesis and functional interpretation. Leadersh Q. 1991;2 (4):245-287. doi:10.1016/1048-9843(91)90016-U

163. Lewin K, Lippitt R. An experimental approach to the study of autocracy and democracy: a preliminary note. Sociometry. 1938;1 (3/4):292-300. doi:10.2307/2785585

164. Golman D. Emotional Intelligence: Why It Can Matter More Than Iq. New York, USA: Bantam Dell; 1995.

165. McGregor D. The Human Side of Enterprise. 1st ed. New York, USA: McGraw-Hill; 1960.

166. Blanchard K, Zigarmi P, Zigarmi D. Leadership and the OneMinute Manager: Increasing Effectiveness Through Situational Leadership ${ }^{\circledR}$ Ii. New York, USA: HarperCollins; 1994.

167. Dansereau F, Graen G, Haga W. A vertical dyad linkage approach to leadership in formal organisations. Organ Behav Hum Perform. 1975;13:46-78. doi:10.1016/0030-5073(75)90005-7

168. Schriesheim CA, Castro SL, Cogliser CC. Leader-member exchange $(\operatorname{lmx})$ research: a comprehensive review of theory, measurement, and data-analytic practices. Leadersh Q. 1999;10 (1):63-113. doi:10.1016/S1048-9843(99)80009-5

169. De Brun A, O’Donovan R, McAuliffe E. Interventions to develop collectivistic leadership in healthcare settings: a systematic review. BMC Health Serv Res. 2019;19(72):22. doi:10.1186/s12913-0193883-x 


\section{Publish your work in this journal}

The Journal of Multidisciplinary Healthcare is an international, peerreviewed open-access journal that aims to represent and publish research in healthcare areas delivered by practitioners of different disciplines. This includes studies and reviews conducted by multidisciplinary teams as well as research which evaluates the results or conduct of such teams or healthcare processes in general. The journal covers a very wide range of areas and welcomes submissions from practitioners at all levels, from all over the world. The manuscript management system is completely online and includes a very quick and fair peer-review system. Visit http://www.dovepress.com/testimonials. php to read real quotes from published authors. 